\title{
A Systematic Review of Exploring the Potential of Teachable Agents in English Learning
}

\author{
Divya Baranwal ${ }^{1 \star}$ (1)
}

${ }^{1}$ PhD Scholar, National Dong Hwa University, TAIWAN

*Corresponding Author: rose.div9@gmail.com

Citation: Baranwal, D. (2022). A Systematic Review of Exploring the Potential of Teachable Agents in English Learning. Pedagogical Research, 7(1), em0117. https://doi.org/10.29333/pr/11553

\begin{tabular}{|c|c|}
\hline ARTICLE INFO & ABSTRACT \\
\hline Received: 16 Jun. 2021 & d learning, Al applications, sl \\
\hline Accepted: 3 Jan. 2022 & $\begin{array}{l}\text { content, personalized tutoring systems, virtual facilitators. This paper aims to review the empirical evidence on } \\
\text { the application of intelligent agents in English learning to define the future research perspectives of Teachable } \\
\text { Agents-assisted English education. After a systematic online data search, the investigator analyzed nine empirical } \\
\text { studies on how Teachable agents have potential English teaching and learning benefits. The results indicate that } \\
\text { (1) most studies conducted with large sample size at university level followed by elementary level, (2) instructional } \\
\text { design were in dialogue and image form, (3) emerged two categories- Interaction and integration, (4) most of them } \\
\text { used experimental research in different settings. This study suggests that TAs substantially play a supportive role, } \\
\text { enhance their involvement, scaffold their learning, and become self-regulated learners. Hence, we prospect the } \\
\text { need for a future-oriented vision regarding Al and intelligent technologies- assisted language learning for non- } \\
\text { native speakers. }\end{array}$ \\
\hline
\end{tabular}

Keywords: language, English learning, teachable agents, self-regulation learning, instructional design

\section{INTRODUCTION}

Language is one of the essential foundations that fabricate international communication activities. Todays' English has become one of the most required languages for jobs, markets, tourism, discourse, international relations (Lan et al., 2020). English language skills involve listening, speaking, reading, and writing for their proficiency and communication (Grabe et al., 2002). Due to the high demand for learning a language for non-native speakers, students face obstacles to learning English (Desselle, 2019) and limited opportunities (Lan et al., 2020). For example, in Asian-Pacific countries such as South Korea, Japan, and Taiwan, English reading and writing have more emphasized at the elementary level (Hwang et al., 2014). Students have experienced various obstacles while fluently English speaking as insufficient content knowledge, limited connection with English outside the classroom (Tokoz, 2014); difficulty in English writing; fear of being scolded by their teachers on their wrong attempt and laughed at by their peers (Cumming et al., 2018); regularity of misspelling (Khan, 2010; Ulicheva, 2018). Here, the teacher's role is crucial in facilitating students' autonomy by promoting learners' responsibility for learning (Holec, 1981). However, the transformation of teaching-learning should occur as chalk-talk traditional is inadequate in the technology era (Susikaran, 2013), and another important aspect is teaching instruction to facilitate language learning (Ahmadi, 2017). Various studies asserted that technology had become an integral part for teachers (Barreto, 2018; Tazhibayeva, 2015) to facilitate learners (Ahmadi, 2018), motivate them, provide unlimited teaching-learning resources (Larsen et al., 2011), transform the language teaching method (Pourhossein Gilakjani, 2017; Solanki \& Shyamlee1, 2012).

With time, the incorporation of technology has changed from CAl to intelligent computer-assisted teaching-learning, significantly enhancing language learning (Kannan et al., 2018). At present, the advancement and uprising of technology play an essential role in every walk of life. We have already entered an era when the human tutor is unavailable, and the next and best option can be a teachable agent. The term 'teachable agents' TAs had emerged in the 1990s. These are intelligent pedagogical agents and can be 'taught' through programming to perform fixed action within the simulation-based environment. It also allows students to teach themselves to ameliorate their learning, explore and solve problems (Biswas et al., 2005). TAs bestow a computer-based learning environment to yield instructions both in verbal and non-verbal mode. TAs embellish students to benefit from visual-audio representations and independent performance to get support, guidance, and feedback (Blair et al., 2006). The potential benefit of TAs is that they can increase students' knowledge reflection and self-explanation (Roscoe \& Chi, 2007). They help them structure and reorganize their knowledge (Fantuzzo et al., 1992) and promote taking responsibility for their learning; however, they do not take the initiatives to interact with students. These systems should be more active to interact as it is essential 
to facilitate better learning (Biswas et al., 2005). On the other hand, TAs have drawbacks, i.e., technical issues, not easy to connect with learners (Reinders \& Pegrum 2016) or misleading feedback, over checking on the reference list, and inability to check context and content of writing (Nova, 2018) which need to accomplish.

In this regard, a systematic review has examined whether teaching-learning with TAs improves English learning, the appropriate instructions used, the significant findings and suggestions, and recommendations in current studies.

\section{Empirical Researches: Some Excerpts}

Studies asserted the role of Intelligent assisting agents as a scaffolding bridge or assistance in creating knowledge (Wood et al., 1976) and helping students achieve their goals. Scaffolding in learning helps to segment the large tasks into small tasks, providing motivation and feedbacks to students (Kim \& Hannafin, 2011). It varies depending on interactions between learners and tutors (planned, adaptive), sources and examples presented (peer, teacher, technology), and the function (implicit, explicit) or the purpose of using scaffolding (conceptual, metacognitive, procedural, strategic) (Kim \& Lim, 2019).

Biswas et al.'s (2010) system mainly addresses reinforcing self-regulated learning that panders to the two self-motivation and self-assessment of an independent learner. Self-regulated learning is an ability to generate thoughts (self-awareness), emotions (self-motivation), actions (behavior skills) that can direct their learning to achieve their goals (Zimmerman, 2008). Technology can facilitate self-regulated learning for those who design and teach in the digital environment, developing self-regulation among students (Barber et al., 2011).

From the social agency point of view, researchers argue that learners may accelerate by verbal and social cues provided by TAs (as cited in Lija et al., 2020). Learner assumes that their relationship with the computer is a social one, as the teacher or peer. Consequently, they may put effort into learning by these agents and enhance learning (Atkinson, 2002). When we look upon the self-determinant theory, individual motivation can group into intrinsic and extrinsic. Intrinsic and extrinsic motivation may lead to verbal and non-verbal communication with a computer-based learning environment. Thereunto, learners with TAs in a computer-based learning environment may positively impact learners' motivation (as cited in Lija et al., 2020).

Heidig and Clarebout (2011) compared fifteen studies with a pedagogical agent condition versus a no-agent state in a systematic review. They found no significant effect of pedagogical effect on learning outcomes or learner motivation. A metaanalysis conducted by Schroeder et al. (2013) included forty-three studies and observed that a pedagogical agent's small, positive effect on learning was not promising. Both studies highlighted a few significant moderators such as modality of instruction, subject domain, and the educational level which, were consistent with the mixed findings in the literature. Choi and Clark (2006) had observed that there was no impact of including a pedagogical agent. Chen (2012) used a pet-styled animated pedagogical agent to teach Chinese Language idioms at elementary level students, which didn't enhance the learning. Although, few empirical studies have even shown that the human voice of a pedagogical agent can have benefits on learning (Atkinson et al., 2005; Louwerse et al., 2005; Park, 2015). Studies mentioned above have provided different perspectives while applying TAs to teach and learn the language, and thus, it increases the relevance of this article. The purpose of this study is to review the research articles and research papers and find out the role of teachable agents in English language learning embedded as supportive or facilitator, what kind of methodology and instruction have used, how the suggestions and recommendations have woven.

\section{Objectives}

This empirical study presents how teachable agents can enhance English learning with an interactive simulation environment. Teachable Agent is novel, and it amalgamates simulation, virtual facilitators, and tutoring, identifies and meets the needs of advanced and struggling students on-demand by personalization. In this regard, the objectives of the present paper are as follows:

1. To study the various role of teachable agents in English learning.

2. To identify the design of the instruction methods for English learning through teachable agents.

3. To study the applied research methods.

4. To find out the empirical findings and look into the conclusion, further recommendations for futuristic work.

\section{METHOD}

Here, for systematic reviews, meta-analysis has conducted to find the various role of teachable agents in English learning in terms of supplement, facilitator, or any disadvantages, no other option. How do they design the instruction method for English learning through teachable agents, what research methods have employed in selected studies, and the findings observed in studies? It addresses the aggregation of results from a set of studies (Gough et al., 2017). Systematic reviews follow three basic steps: searching the literature, screening abstracts, and full-text document inclusion, and lastly, unbiased screening.

\section{Search Procedure}

The following search criteria are set as follows:

1. Studies related to "teachable agents”; 'English learning'; 'teachable agents for English'; related terms 'English learning and technology'; 'English language and instructions'; 'ITS and English learning'; English Language and Meta-Analysis.

2. It should be the availability and accessibility of full text.

3. The study should be available from 2015-2019 till date. 


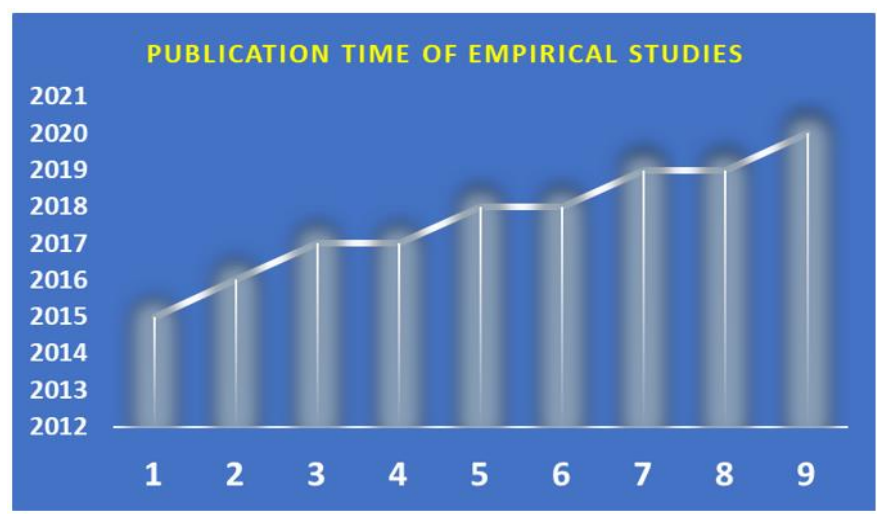

Figure 1. Publication time of Empirical Studies

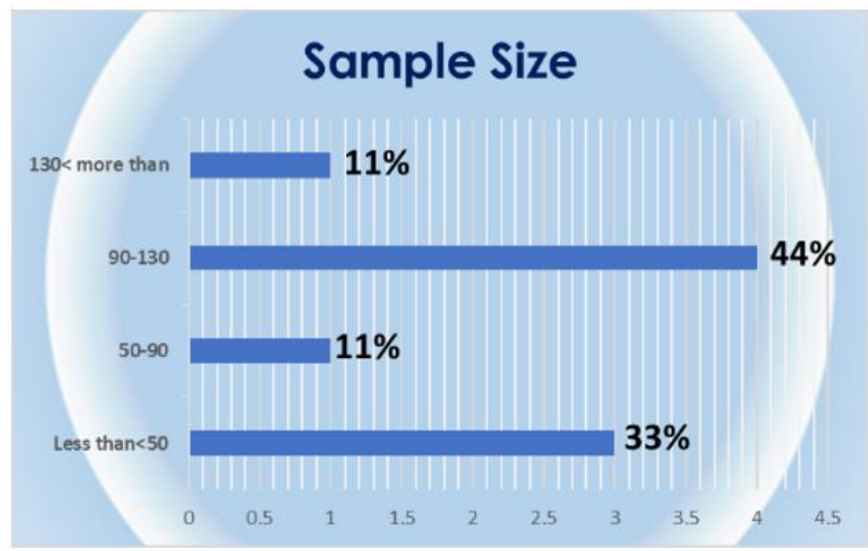

Figure 2. Sample sizes of these empirical studies

\section{Included Databases}

Eric peer-reviewed, Cambridge Core Journals, Academia, Science Direct, and Peer-Reviewed e-Journals of technology are included as databases. The search was carried out and resulted, as follows:

1. 641 matches-English learning and intelligent technology

2. 8809 matches-Language learning and technology

3. 308 matches-ITS and English learning

4. 70 matches-English Language and Meta-Analysis.

5. 16 matches-teachable agents and English

\section{Unbiased Screening}

The next step is to do an unbiased screening of eligible studies for the present meta-analysis. Pigott (2019) and Polanin and Terzian (2019) provide a set of best practices that help guide the meta-analyst in conducting these processes reliably and efficiently and suggest that screening commonly begins with small screening tools used on title and abstract to eliminate unmatched articles. Thus, to eliminate the ineligible and irrelevant search matches, the researcher narrowed them down to 30 papers. The investigator selected only nine documents that fulfilled the above research criteria and scrutinized the studies. The selection procedure of studies has completed from Dec 2019 to Jan 2020. The aim of selecting papers from 2015 to 2019 is to observe the current trend, challenges, implications, suggestions regarding TAs in the day-to-day classrooms.

\section{Analysis}

It is observed that most participants belong to non-native English-speaking countries i.e., Chinese, Portuguese, Turkish, and Spanish (Appendix A, Table A1). Mostly they learn English as a second language after they have already practiced it for some period. For instance, some traveled to English-speaking countries for six months, recently completed their EFL classes, etc. The publications time of empirical studies has shown in Figure 1.

Furthermore, Figure 2 shows the samples groups used in 9 papers. Three or 33\% of the documents involved less than 50 participants, one or $11 \%$ recruited 50-90 in their experiments, and one of them has used more than 130 , while four or $44 \%$ involved the 90-130 participants for the study. According to Table A1 of Appendix A, the largest group were university students (6 or $66 \%$ ), followed by elementary level students ( 3 or $33 \%$ ). It indicates that the university group is more focused than others and the sample size is large. 


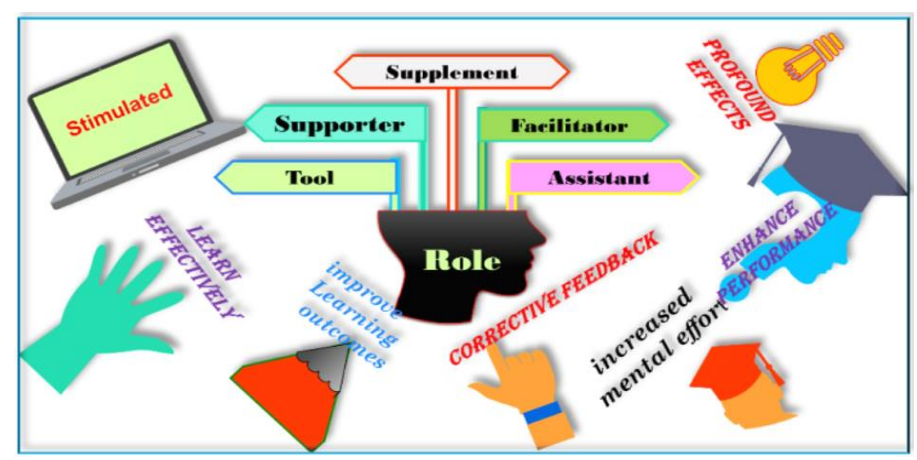

Figure 3. Various roles of TAs

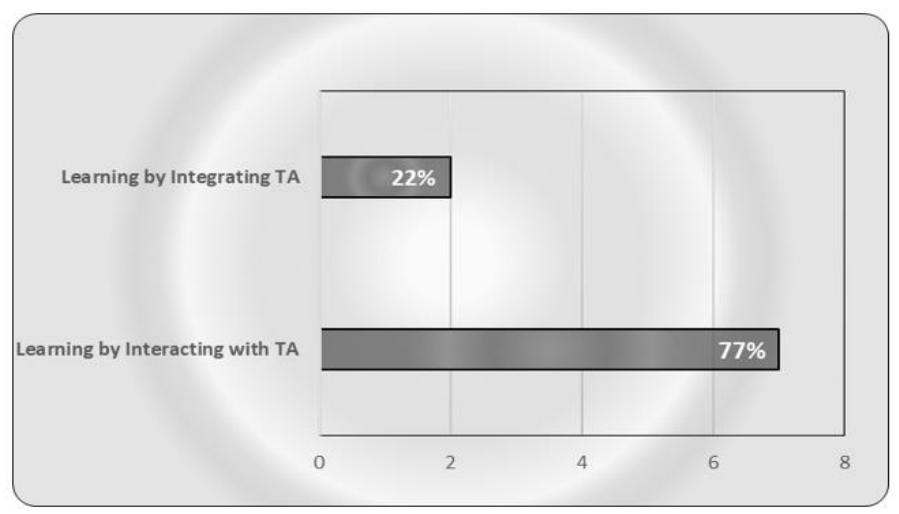

Figure 4. Way of integration and Interaction with TAs

Table 1. Involved English learning

\begin{tabular}{|c|c|c|c|c|c|c|c|c|c|}
\hline English knowledge vs. papers & 1 & 2 & 3 & 4 & 5 & 6 & 7 & 8 & 9 \\
\hline Pronouns & $\sqrt{ }$ & & & & & & & & \\
\hline Phrases & $\sqrt{ }$ & & & & & & & & \\
\hline Vocabulary test & & $\sqrt{ }$ & & & & & $\sqrt{ }$ & & \\
\hline Grammar test & & & $\sqrt{ }$ & $\sqrt{ }$ & & & & $\sqrt{ }$ & \\
\hline English proficiency & & $\sqrt{ }$ & & & & $\sqrt{ }$ & & & \\
\hline Relative clauses & & & $\sqrt{ }$ & & & & & & \\
\hline Reading comprehension & & & & & & & & & $\sqrt{ }$ \\
\hline Speaking test & & & & & & $\sqrt{ }$ & & & \\
\hline Perception test & & & & & $\sqrt{ }$ & & & & \\
\hline
\end{tabular}

\section{To study the various role of teachable agents in English learning}

Regarding general information (see Table A1 of Appendix A), studies mentioned the specific teachable agents as pedagogical agents; two papers used female animated character TA, digital technologies, auto tutor app, and motion-sensing interactive system. It has observed that teachable agents support students learning as a supplement, facilitator, clicker as a supplementary tool (Figure 3).

\section{To identify the design of the instruction methods for English learning through teachable agents}

For the present study, identifying the design of instruction methods includes integration and interactions, areas of English learning, and different form of TAs, which highlight how learning has occurred. In the selected paper, the investigator observed two emerged categories in terms of integration and Interaction of TAs in English learning (Figure 4). 7 or $77.7 \%$ of the papers taught English using student-TA's interaction, for example, system-initiative dialogue corpus app, conversation model-auto tutor software, Kinect motion-sensing interactive system (KMIS) and an interactive game, static images that can breathe and speak with lip movements, can also move around the screen and point to content and nods in approval for correct answers and shows an expression of confusion. The two or $22.2 \%$ taught by integrating TA as clickers or web browsing learnin materials.

As observed in Table 1, two papers specifically focused on the grammar test. At the same time, one article dealt with both grammar and relative clauses. One piece used pronouns and phrases; one of them focalized on vocabulary tests and language proficiency. Another one was aimed at English proficiency and speaking test; one of the papers involved English vocabulary cognition, and only one paper concerned reading comprehension.

Here, the most commonly observed instructional design of TAs is dialogue form, in image form, which interacts with students, engages them, monitors their progress, and provides feedback (Figure 5 and Figure 6). 


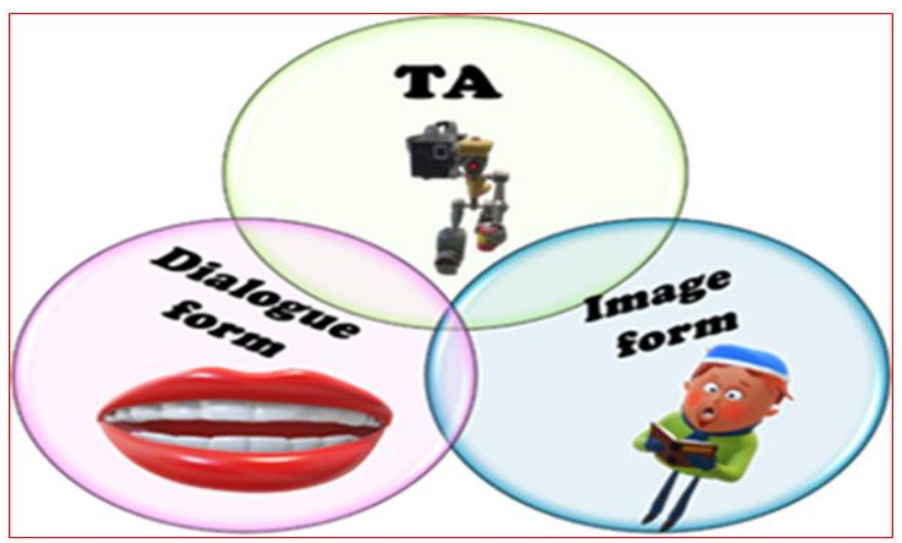

Figure 5. Forms of TAs

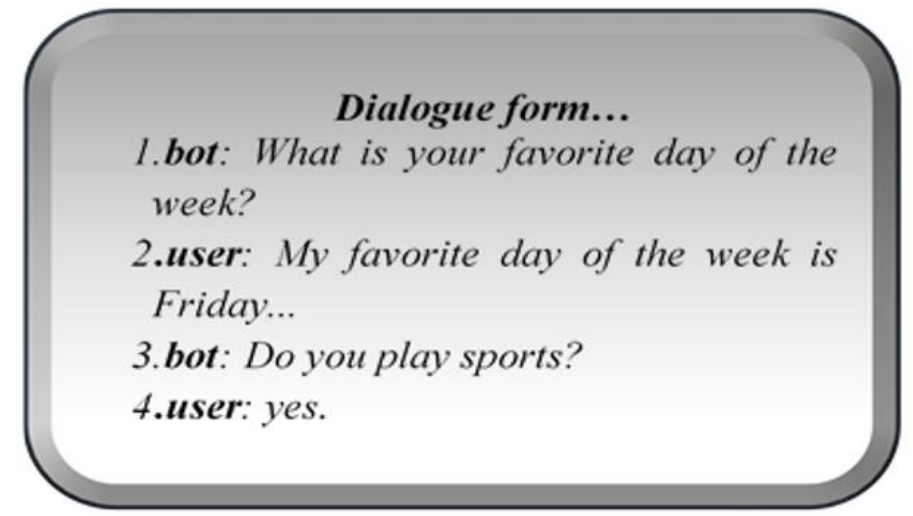

Figure 6. Excerpts of dialogue form

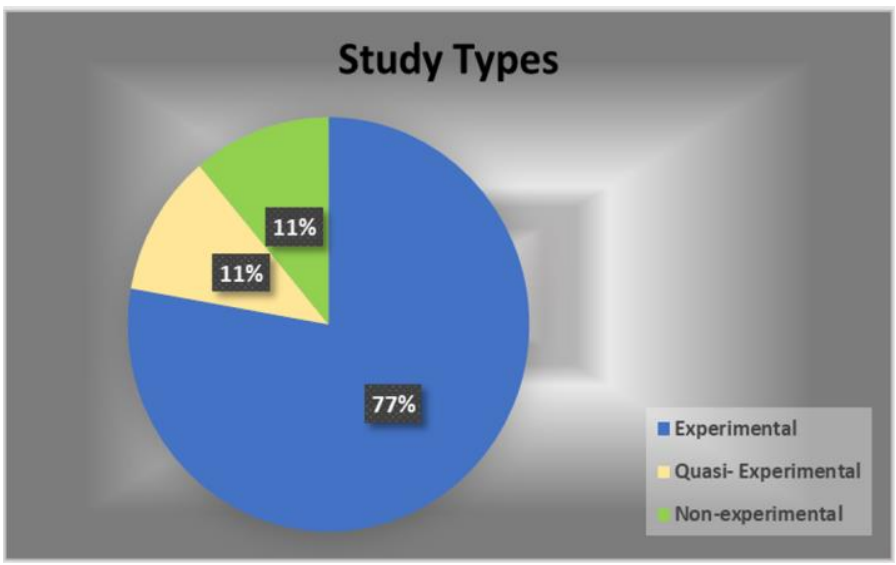

Figure 7. Study type of these empirical studies

\section{To study the applied research methods}

In this section, we have discussed the intervention, instruments methods reported in nine papers. The detailed layout has presented in Table A2 of Appendix B. As observed, we have classified the study design into experimental (7 or $77 \%)$, quasiexperimental ( 1 or $11 \%$ ), and non-experimental research design (11\%) (see Figure 7 ). In experimental research, pre-test, treatment- interacted with TA, post-test conducted and perception study organized. The benefits of experimental investigations are that they provide a specific conclusion. As per Figure 2, 44 percentage of papers included a 90-130 range of sample size.

Different data collection method has been used in selected papers to get in-depth information. Table 2 observed that openended surveys, questionnaires, multiple choice of questions, checklists, oral tests, demographic surveys, and reading comprehension tests were conducted in selected papers. Some of the documents employed more than one method for evaluation. Besides this, a distinct practice was found in these papers i.e. Lin et al. (2020) measured retention test, transfer test, cognitive load, and intrinsic motivation; Sinclair et al. (2019) measured corpora and corpus using the Toolkit scikit and BayesianGaussianMixture model. As observed in Table A2 of Appendix B, most of the researchers have used ANOVA and ANCOVA. In contrast, few have nonparametric tests, i.e., Mann-Whitney U test, Wilcoxon Signed, and descriptive statistics. 
Table 2. Data collection methods of these empirical studies

\begin{tabular}{|c|c|c|c|c|c|c|c|c|c|}
\hline Measuring tools vs. papers & 1 & 2 & 3 & 4 & 5 & 6 & 7 & 8 & 9 \\
\hline Survey & $\sqrt{ }$ & & & & $\sqrt{ }$ & & & & \\
\hline Questionnaire & $\sqrt{ }$ & & $\sqrt{ }$ & $\sqrt{ }$ & & $\sqrt{ }$ & & $\sqrt{ }$ & \\
\hline MCQ & & & $\sqrt{ }$ & $\sqrt{ }$ & & & $\sqrt{ }$ & & \\
\hline Checklist & $\sqrt{ }$ & & & & & & & & \\
\hline Oral test & & & $\sqrt{ }$ & & & & & & \\
\hline Demographic survey & $\sqrt{ }$ & & & & & & & & \\
\hline Reading comprehension test & & & & & & & & & $\sqrt{ }$ \\
\hline
\end{tabular}

\section{To find out the empirical findings in studies and look into the conclusion, further recommendations for futuristic work}

The analysis of findings, conclusions, and further recommendations for futuristic work in the studies reviewed led to astonishing observations (see Table A2 of Appendix B). Most researchers support teachable agents as they are accommodating for language learning through interaction with students, provide feedback, help them to build new knowledge from existing knowledge (constructivist learning), guide them to discover learning opportunities, problem-solving (exploratory learning), and also help them to define learning goals and monitor their progress in achieving them (metacognitive-strategies) (Biswas et al., 2005). TA intelligent system allows positive acquisition of language learning as a reading skill, writing, vocabulary, grammar, language proficiency, enhancement students' engagements. It fosters the development of self-regulated learning among students and influences English proficiency of non-native English speakers, such as language aptitude, motivation, anxiety, self-esteem, and learning strategy. It increases students' interest and scaffolds their learning by fostering critical thinking skills. Future suggestions should conduct on large sample size, related to gender ethnicity, by practically implementing more interactive activities, more comprehensive qualitative, quantitative, and/ or mixed studies, and longitude effectiveness in different adaptively instructional designs.

\section{DISCUSSION}

Notwithstanding the widespread consent of English language teaching and learning, a firm challenge remains to provide learners feasible opportunities to produce the intended language orally to become eloquent and persuasive in speaking or writing (McDonough \& Sato, 2019). It is not very easy to make them learn, but, continuous repetition or rehearsal of activities can understand through the reference to skill acquisition theory (DeKeyser, 2001, 2007a, 2017) which states that learning language begins with the acquisition of declarative knowledge. With the help of repeated practices of declarative knowledge, learners will enable them to achieve procedural knowledge. (Tavakoli et al., 2016).

It has observed that most participants belong to non-native English-speaking countries or those who have English as a second language. They need a longer time framework (McDonough, 2019), which develops automatized knowledge that establishes eloquent and persuasive language use. For non-native English speakers, technology development made the learning process easier and faster; it enriched to keep up with the world's development and critical thinking (Gurgenidze, 2018). Researchers identified that shaping an individual's attitudes toward using technology is a significant issue (as cited in Ngo \& Eichelberger, 2019). English learners tend to have a positive attitude towards using technology for their learning (Nguyen \& Nguyen, 2016). Besides, the instructional goal is essential to help students develop their persuasiveness and eloquence during interaction and unplanned language use.

Implementing TAs for language learning allows for functionalities such as virtual instructors to clarify the topics or answer the questions as required (Alhabbash et al., 2016; Elen, 2016). It has observed that these teachable agents support the students learning as a supplement, facilitator. Learning with an animated pedagogical agent is a more exciting and effective tool (Ahmadi, 2018). The students had explicit information about relative clause formation in a previous EFL course (McDonough, 2019) and a higher tendency to feel that clickers stimulated them in the class. It may also use as a supplementary tool to enhance the performance of the class ESP learners (Asmali, 2018). Pan (2017) regarded with novel Kinect motion-sensing interface perhaps could be applied to attract students' attention or amplify motivation to vocabulary learning compared to a-way rote memorization of vocabulary practiced in schools one decade ago.

Based on the personalization principle, pedagogical agent instruction in conversation and interactive style may amplify the in-depth and insightful learning (Mayer, 2014) and positive effect on learning outcomes, learner's performance on retention (Ginns et al., 2013), enhance learners' engagement, increase the mental efforts, reduce the cognitive load (Li et al., 2015). These peer agents' competencies in the educational ITS should adaptively designed to consider the trade-off of learning outcomes and engagement (Li et al., 2015).

Learners can enhance their language skills, performance, cooperatively work together to task analysis, self-monitoring, learn through peers (as cited in Ahmadi, 2018). It reflects the intelligent system support to be a self-regulated learner. These intelligent agents support learners by providing appropriate feedback, clues for completing their tasks (Mohammadzadeh \& Sarkhosh, 2018). However, these are thought-provoking results that novice technologies profoundly affect self-directed learning in the English language classroom. Beyond the classroom, it is more resilient, re-constructivism, and regulated where the teacher plays a pivotal role.

Integration and Interaction with TAs in English learning show that instructional design is the utmost significant part of the curriculum, how the instructions have planned for the teaching-learning process and how technology takes part in an interactive 
learning process. Using intelligent technologies promulgated language teaching in three junctures, i.e., fosters interaction and communication in the classroom, helps to confer new cultural and linguistic elements, improves teaching skills (Gerard et al., 1999), and connects and collaborates develops critical thinking learners, boosts self-reliance and self-assurance among learners. The interactivity learning process amalgamates the joint task of instructors and learners (Abykanova et al., 2016). Interactive technologies can provide systematic practice for language learning, such as modeling peer agent interaction, training the skill of how to interact (as cited in McDonough, 2019). Integrating interactive technologies and communicative activities in language learning bestow opportunities and potential benefits (Asamli, 2018). For example, one of the articles used corpora that not merely ameliorating vocabularies specific to students' fields (Fuente, 2007) rather also learner's academic writing proficiency (Lee \& Swales, 2006) and help confer students to make fewer mistakes, ameliorate lexicon- grammar and language awareness (Yoon, 2008). The learner learns quickly, questions and clarifications can ask freely, leading to a comprehensive learning experience when the one-to-one session with a virtual instructor would occur and alleviate cognitive loads on the learning experience.

Based on the sample size discussed in Figure 2, we can generalize the conclusion to the broader community. Another important factor, the research should be parsimonious, but it has observed that few researchers in selected papers had paid money for participating as a sample in their study. It's affected the sampling process and authenticity in an empirical domain, which does not make research more easily generalizable (Aarts, 2007).

Although these researches were conducted on non-native English speakers and their English learning from school to college, they still cannot speak, listen, read, or even write (Wu \& Zhang, 2019). Perhaps numerous factors influence the English proficiency of non-native English speakers, such as language aptitude, motivation, anxiety, self-esteem, and learning strategy (as cited in Wu, 2019). They have little chance to learn English as a foreign language, but they're a positive attitude towards language learning (Asmali, 2018). The studies support there is no doubt to use the TA intelligent system. They are accommodating for language learning and can teach the skills of listening, spelling, writing, and conversation in the English language (Mohammed et al., 2016). Students are attracted to the animated agents and voice of the intelligence system (Lin et al. 2020) and foster to development of self-regulated learning among students. Overall, it can observe that students improve their spontaneous proficiency skills, use of relative clauses, the complicated structure of grammar over a short period (McDonough, 2019) to amplify long-term English vocabulary retention (Pan, 2017).

\section{CONCLUSIONS}

The achieved results and future implications are reported in this section. A systematic empirical study has been conducted to find out the various role of TAs in English language learning. As artificial intelligence systems open up new horizons, numerous studies have explored the role of intelligent systems in learning the language. However, the selected studies mainly focused on the use of teachable agents in language learning conducted on non-native English speakers. The following conclusions have been reached:

1. Support the students' learning as a supplement, assistant, facilitator, clicker as a supplementary tool.

2. Interaction and integration have emerged as two categories in this review study, i.e., interaction with system-initiative dialogue corpus app, conversation model- auto tutor software, Kinect motion-sensing interactive system (KMIS), an interactive game, static images that can breathe and speak with lip movements and integrating as in terms of clickers or web browsing learning materials.

3. Learn grammar and relative clauses; vocabulary test; speaking proficiency; vocabulary cognition; reading comprehension; pronouns and phrases.

4. Animated and human-like voices of TAs contribute more positively to enhance students' engagement; improve retention, motivation, and reduced cognitive load; increase students' interest; foster critical thinking skills; allow them to be selfregulated learners.

5. TAs system bestows equal opportunities to all students.

6. Most studies used experimental research in different settings.

7. The analysis of findings, conclusions, and further recommendations for futuristic work in the studies reviewed led to astonishing observations, i.e., spontaneous proficiency skills, and recommended that it be conducted on a large-scale sample with a different domain in the future.

The findings of our study have theoretical and practical implications. From the social agency theory point of view, can predict the effect on learners' interest taken by a pedagogical agent if instructions are optimally designed; otherwise, they are merely for entertainment. Instructional designers have to spend time creating exceptional instruction, assessment, and feedback for different learning styles at various levels. It may, therefore, be necessary to develop appropriate discernment and policies by simultaneously creating future-oriented models for education and teaching. Consequently, teachers who often struggle with the concrete demands of everyday teaching practice and new initiatives mustn't be electrocuted by this new technology. To overcome the day-to-day teaching-learning challenges, particularly the English language, Teachable agents, "the artificial intelligence assisting tools," will play a panacea. And it will redound the students' learning as a supporter, facilitator, assistant to procreate self-regulation among them and ameliorate language learning acquisition positively. With concluding remarks, the investigator can suggest that specific activities for second language learning should engross students' continual and deliberate pursuit of selfefficacy, skills, proficiency, and obtain knowledge. 
Author contributions: The author has agreed with the results and conclusions.

Funding: No funding source is reported for this study.

Declaration of interest: No conflict of interest is declared by author.

\section{REFERENCES}

Aarts, K. (2007). Parsimonious methodology. Methodological Innovations Online, 2(1), 2-10. https://doi.org/10.4256/mio.2007.0002

Abykanova, B., Nugumanova, S., Yelezhanova, S., Kabylkhamit, Z., \& Sabirovaa, Z. (2016). The use of interactive learning technology in institutions of higher learning. International Journal of Environmental \& Science Education, 11(18), 12528-12539. https://files.eric.ed.gov/fulltext/EJ1124626.pdf

Ahmadi, M. R. (2017). The impact of motivation on reading comprehension. International Journal of Research in English Education, 2(1), 1-7. https://doi.org/10.18869/acadpub.ijree.2.1.1

Ahmadi, M. R. (2018). The use of technology in English language learning: A review literature. International Journal of Research in English Education, 3(2), 115-125. https://doi.org/10.29252/ijree.3.2.115

Alhabbash, M. I., Mahdi, A. O., \& Abu-Naser, S. S. (2016). An intelligent tutoring system for teaching grammar English tenses. European Academic Research, 4(9), 1-15.

Asmali, M. (2018). Integrating technology into ESP classes: Use of student response system in English for specific purposes instruction. Teaching English with Technology, 18(3), 86-10. https://files.eric.ed.gov/fulltext/EJ1186385.pdf

Atkinson, R. K. (2002). Optimizing learning from examples using animated pedagogical agents. Journal of Educational Psychology, 94(2), 416-427. https://doi.org/10.1037/0022-0663.94.2.416

Atkinson, R. K., Mayer, R. E., \& Merrill, M. M. (2005). Fostering social agency in multimedia learning: Examining the impact of an animated agent's voice. Contemporary Educational Psychology, 30(1), 117-139. https://doi.org/10.1016/j.cedpsych.2004.07. 001

Barber, L. K., Bagsby, P. G., Grawitch, M. J., \& Buerck, J. P. (2011). Facilitating self-regulated learning with technology: Evidence for student motivation and exam improvement. Teaching of Psychology, 38(4), 303-308. https://doi.org/10.1177/ 0098628311421337

Barreto, A. M. R. (2018). Motivating English language use by using the benefits of technology. Gist Education and Learning Research Journal, 16, 117-140. https://doi.org/10.26817/16925777.428

Biswas, G., Jeong, H., Kinnebrew, J., Sulcer, B., \& Roscoe, R. (2010). Measuring self-regulated learning skills through social interactions in a teachable agent environment. Research and Practice in Technology-Enhanced Learning, 5, $123-152$. https://doi.org/10.1142/S1793206810000839

Biswas, G., Leelawong, K., Schwartz, D., Vye, N., \& TAG-V. (2005). Learning by teaching: A new agent paradigm for educational software. Applied Artificial Intelligence, 19(3-4), 363-392. https://doi.org/10.1080/08839510590910200

Blair, K., Schwartz, D., Biswas, G., \& Leelawong, K. (2006). Pedagogical agents for learning by teaching: Teachable agents. Educational Technology \& Society, 47.

Chen, Z. H. (2012). We care about you: Incorporating pet characteristics with educational agents through a reciprocal caring approach. Computers \& Education, 59, 1081-1088. https://doi.org/10.1016/j.compedu.2012.05.015

Choi, S., \& Clark, R. E. (2006). Cognitive and affective benefits of animated pedagogical agents for learning a second language. Journal of Educational Computing Research, 34(4), 441-466. https://doi.org/10.2190/A064-U776-4208-N145

Cumming, A., Yang, L., Qiu, C., Zhang, L., Ji, X., Wang, J., Wang, Y., Zhan, J., Zhang, F., Xu, C., Cao, R., Yu, L., Chu, M., Liu, M., Cao, M., \& La, C. (2018). Students' practices and abilities for writing from sources in English at universities in China. Journal of Second Language Writing, 39, 1-15. https://doi.org/10.1016/j.jslw.2017.11.001

DeKeyser, R. (2001). Automaticity and automatization. In P. Robinson (Ed.), Cognition and second language instruction (pp. 125151). Cambridge University Press. https://doi.org/10.1017/CBO9781139524780.007

DeKeyser, R. (2007a). Skill acquisition theory. In B. VanPatten, \& J. Williams (Eds.), Theories in second language acquisition: An introduction (pp. 97-114). Lawrence Erlbaum.

DeKeyser, R. (2017). Knowledge and skill in ISLA. In S. Loewen, \& M. Sato (Eds.), The Routledge handbook of instructed second language acquisition (pp. 15-32). Routledge. https://doi.org/10.4324/9781315676968-2

Desselle, S. P. (2019). Native English speakers and English as a foreign language (EFL) students' performance and notetaking in a doctor of pharmacy health systems course. Research in Social and Administrative Pharmacy, 15(9), $1154-1159$. https://doi.org/10.1016/j.sapharm.2018.09.023

Elen, J. (2016). Reflections on the future of instructional design research. In J. Spector, D. Ifenthaler, D. Sampson, \& P. Isaias (Eds.), Competencies in teaching, learning and educational leadership in the digital age. Springer. https://doi.org/10.1007/978-3-31930295-9_1

Fantuzzo, J. W., King, J. A., \& Heller, L. R. (1992). Effects of reciprocal peer tutoring on mathematics and school adjustment: A component analysis. Journal of Educational Psychology, 84(3), 331-339. https://doi.org/10.1037/0022-0663.84.3.331 
Gerard, F., Greene, M., \& Widener, J. (1999). Using SMART board in foreign language classes. Reports (142). https://files.eric.ed.gov/ fulltext/ED432278.pdf

Ginns, P., Martin, A. J., \& Marsh, H. W. (2013). Designing instructional text in a conversational style: A meta-analysis. Educational Psychology Review, 25(4), 445-472. https://doi.org/10.1007/s10648-013-9228-0.

Gough, D., Oliver, S., \& Thomas, J. (2017). An introduction to systematic reviews. SAGE.

Grabe, W., \& Stoller, F. L. (2002). Teaching and researching reading. Pearson Education. https://doi.org/10.4324/9781315833743

Gurgenidze, M. (2018). Technology assisted English language learning and its possible benefits in Georgia. International Journal of Technology in Education and Science, 2(1), 31-34. https://eric.ed.gov/?id=EJ1227073

Heidig, S., \& Clarebout, G. (2011). Do pedagogical agents make a difference to student motivation and learning? Educational Research Review, 6(1), 27-54. https://doi.org/10.1016/j.edurev.2010.07.004

Holec, H. (1981). Autonomy and foreign language learning. Pergamon. (First published 1979, Council of Europe).

Hwang, W.-Y., Huang, Y.-M., Shadiev, R., Wu, S.-Y., \& Chen, S.-L. (2014). Effects of using mobile devices on English listening diversity and speaking for EFL elementary students. Australasian Journal of Educational Technology, 30(5), 503-516. https://doi.org/10.14742/ajet.237

Kannan, J., \& Munday, P. (2018). New trends in second language learning and teaching through the lens of ICT, networked learning, and artificial intelligence. Circle of Linguistics Applied to Communication, 76, 13-30. https://doi.org/10.5209/CLAC.62495

Khan, N. (2010). Improving the speaking ability in English: The students' perspective. Elsevier: Procedia - Social and Behavioral Sciences, 2(2), 3575-3579. https://doi.org/10.1016/j.sbspro.2010.03.554

Kim, J. Y., \& Lim, K. Y. (2019). Promoting learning in online, ill-structured problem solving: The effects of scaffolding type and metacognition level. Computers \& Education, 138, 116-129. https://doi.org/10.1016/j.compedu.2019.05.001

Kim, M. C., \& Hannafin, M. J. (2011). Scaffolding problem solving in technology-enhanced learning environments (TELEs): Bridging research and theory with practice. Computers \& Education, 56(2), 403-417. https://doi.org/10.1016/j.compedu.2010.08.024

Lan, P.-S., Liu, M.-C., \& Baranwal, D. (2020). Applying contracts and online communities to promote student's self-regulation in English learning at the primary-school level. Interactive Learning Environments. https://doi.org/10.1080/10494820.2020. 1789674

Larsen-Freeman, D., \& Anderson, M. (2011). Techniques and principles in language teaching. OUP.

Lee, D., \& Swales, J. (2006). A corpus-based EAP course for NNS doctoral students: Moving from available specialized corpora to self-compiled corpora. English for Specific Purposes, 25(1), 56-75. https://doi.org/10.1016/j.esp.2005.02.010

Li, H., Cheng, C., Yu, Q., \& Graesser A. C. (2015). The role of peer agent's learning competency in trialogue-based reading intelligent systems. In C. Conati, N. Heffernan, A. Mitrovic, \& M. F. Verdejo (Eds.), Proceedings of 17th International Conference on Artificial Intelligence in Education, 694-697. Springer. https://doi.org/10.1007/978-3-319-19773-9_94

Lin, L., Ginns, P., Wang, T., \& Zhang, P. (2020). Using a pedagogical agent to deliver conversational style instruction: What benefits can you obtain? Computers \& Education, 143, 103658. https://doi.org/10.1016/j.compedu.2019.103658

Louwerse, M. M., Graesser, A. C., Lu, S., \& Mitchell, H. H. (2005). Social cues in animated conversational agents. Applied Cognitive Psychology, 19(6), 693-704. https://doi.org/10.1002/acp.1117

Mayer, R. E. (2014). Principles based on social cues in multimedia learning: Personalization, voice, image, and embodiment principles. In R. E. Mayer (Ed.), The Cambridge handbook of multimedia learning (pp. 345-368). Cambridge University Press. https://doi.org/10.1017/CBO9781139547369.017

McCarty, S., Obari, H. S., \& Sato, T. (2017). Implementing mobile language learning technologies in Japan. SpringerBriefs in Education. https://doi.org/10.1007/978-981-10-2451-1_1

McDonough, K., \& Sato, M. (2019). Promoting EFL students' accuracy and fluency through interactive practice activities. Studies in Second Language Learning and Teaching, 9(2), 379-395. https://doi.org/10.14746/ssllt.2019.9.2.6

Mohammadzadeh, A., \& Sarkhosh, M. (2018). The effects of self-regulatory learning through computer-assisted intelligent tutoring system on the improvement of EFL learner' speaking ability. International Journal of Instruction, 11(2), 167-184. https://doi.org/10.12973/iji.2018.11212a

Ngo, H., \& Eichelberger, A. (2019). College students' attitudes toward ICT Use for English learning. International Journal of Education and Development using Information and Communication Technology, 15(1), 14. https://eric.ed.gov/?id=EJ1214377

Nguyen, T. T., \& Nguyen, T. K. T. (2016). Oral English communication strategies among Vietnamese non-majors of English at intermediate level. American Journal of Educational Research, 4(3), 283-287. https://doi.org/10.5746/LEiA/16/V7/I1/A02/ Nguyen

Nova, M. (2018). Utilizing grammarly in evaluating academic writing: A narrative research on EFL students' experience. Premise Journal, 7(1), 80-96. https://doi.org/10.24127/pj.v7i1.1332

Pan, W. F. (2017). The effects of using the Kinect motion-sensing interactive system to enhance English learning for elementary students. Educational Technology \& Society, 20(2), 188-200. https://eric.ed.gov/?id=EJ1137513

Park, S. (2015). The effects of social cue principles on cognitive load, situational interest, motivation, and achievement in pedagogical agent multimedia learning. Journal of Educational Technology \& Society, 18(4), $211-229$. http://www.jstor.org/stable/jeductechsoci.18.4.211 
Pigott, T. D. (2019). Missing data in meta-analysis. In H. Cooper, L. V. Hedges, \& J. C. Valentine (Eds.), The handbook of research synthesis and meta-analysis. SAGE. https://doi.org/10.7758/9781610448864.20

Polanin, J. R., \& Terzian, M. (2019). A data-sharing agreement helps to increase researchers' willingness to share primary data: Results from a randomized controlled trial. Journal of Clinical Epidemiology, 106, 60-69. https://doi.org/10.1016/j.jclinepi.2018.10.006

Pourhossein Gilakjani, A. (2017). A review of the literature on the integration of technology into the learning and teaching of English language skills. International Journal of English Linguistics, 7(5), 95-106. https://doi.org/10.5539/ijel.v7n5p95

Reinders, H., \& Pegrum, M. (2016). Supporting language learning on the move: An evaluative framework for mobile language learning resources. In B. Tomlinson (Ed.), SLA research and materials development for language learning. Routledge.

Roscoe, R. D., \& Chi, M. T. H. (2007). Understanding tutor learning: Knowledge-building and knowledge-telling in peer tutors' explanations and questions. Review of Educational Research, 77(4), 534-574. https://doi.org/10.3102/0034654307309920

Schroeder, N. L., Adesope, O. O., \& Gilbert, R. B. (2013). How effective are pedagogical agents for learning? A meta-analytic review. Journal of Educational Computing Research, 49 (1), 1-39. https://doi.org/10.2190/EC.49.1.a

Sert, N., \& Boynuegri, E. (2017). Digital technology use by the students and English teachers and self-directed language learning. World Journal on Educational Technology: Current Issues, 9(1), 24-34. https://doi.org/10.18844/wjet.v9i1.993

Sinclair, A., McCurdy, K., Lopez, A., Lucas, C., \& Gasevic, D. (2019). Tutorbot corpus: Evidence of human-agent verbal aignment in second language learner dialogues. In C. F. Lynch, A. Merceron, M. Desmarais, \& R. Nkambou (Eds.), Proceedings of The 12th International Conference on Educational Data Mining (pp. 414-419).

Solanki, D., \& Shyamlee1, M. P. (2012). Use of technology in English language teaching and learning: An analysis. International Conference on Language, Medias and Culture. IACSIT Press, Singapore. 150-156.

Susikaran, R. S. A. (2013). The use of multimedia in English language teaching. Journal of Technology for ELT, 1(1), 29-38.

Tavakoli, P., Campbell, C., \& McCormack, J. (2016). Development of speech fluency over a short period of time: Effects of pedagogic intervention. TESOL Quarterly, 50, 447-471. https://doi.org/10.1002/tesq.244

Tazhibayeva, E. R. (2015). Multimedia tools for developing creativity in the English classroom. https://articlekz.com/en/article/14591

Tokoz, F. (2014). Speaking problems of 9th grade high school Turkish learners of L2 English and possible reasons for those problems: Exploring the teachers and students' perspectives. Elsevier: Procedia - Social and Behavioral Sciences, 116, 18751879. https://doi.org/10.1016/j.sbspro.2014.01.487

Ulicheva, A. (2018). Skilled readers' sensitivity to meaningful regularities in English writing. Cognition, 185. https://doi.org/10.1016/ j.cognition.2018.09.013

Wood, D., Bruner, J. S., \& Ross, G. (1976). The role of tutoring in problem solving. The Journal of Child Psychology and Psychiatry and Allied Disciplines, 17(2), 89-100. https://doi.org/10.1111/j.1469-7610.1976.tb00381.x

Wu, J. G., \& Zhang, D. (2019). Why did you suggest voice messages but never use it anyway? Obstacles of promoting English language speaking in a mobile instant messaging community. The 18th World Conference on Mobile and Contextual Learning. Deflt, Netherlands.

Wu, Y. (2019). Non-English mjor students' perception of factors influencing English proficiency in China. English Language Teaching, 12(4), 157. https://doi.org/10.5539/elt. v12n4p157

Yoon, H. (2008). More than a linguistic reference: The influence of corpus technology on L2 academic writing. Language Learning \& Technology, 12(2), 31-48. https://eric.ed.gov/?id=EJ805512

Zimmerman, B. J. (2008). Investigating self-regulation and motivation: Historical background, methodological developments, and future prospects. American Educational Research Journal,45(1), 166-183. https://doi.org/10.3102/0002831207312909 


\section{APPENDIX A}

Table A1. General information of the reviewed papers

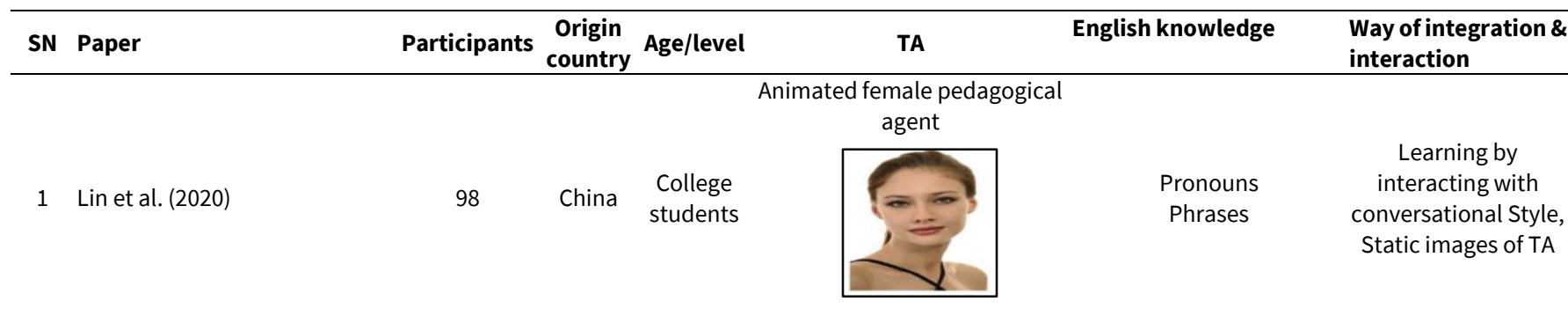

2 Sinclair et al. (2019) $118 \quad$ Scotland $\begin{array}{cc}1-4 & \text { Automated dialogue agent } \\ \text { Grade L2 } & \text { Tutorbot }\end{array}$

Vocabulary test Language proficiency
Learning by

interacting with TA a

dialogue corpus app,

System-initiative

dialogue with

extensive guidance

Learning by

interactive activities with TA

Learning by

integrating web

browser learning materials

Learning by

integrating digital technology

Learning by

interacting

computer-assisted

intelligent tutoring system and

conversation modelautotutor software

Learning by Kinect motion-sensing interactive system (KMIS) and an interactive game with a questioning strategy

Learning by interacting with static images that can breathe and lip movements while speaking, can also move around the screen and point to content, nods in approval for correct answers, and expresses confusion

Reading comprehension Two conversational computer questions and students' 9 Li et al. (2015)

\section{Learning wit} interacted with the agents system self-efficacy and attitudes toward the peer agent 
APPENDIX B

Table A2. Research Methodology and woven suggestions

\begin{tabular}{|c|c|c|c|c|c|c|}
\hline SN & Paper & Intervention & Measurement instrument & $\begin{array}{c}\text { Measurement } \\
\text { methods }\end{array}$ & Major findings & Further recommendations \\
\hline 1 & $\begin{array}{l}\text { Lin et al. } \\
(2020)\end{array}$ & $\begin{array}{c}\text { Experimental } \\
\text { visual presence of an } \\
\text { animated pedagogical } \\
\text { agent (agent vs. no agent). } \\
\text { conversational-styled } \\
\text { material (conversational } \\
\text { style vs. formal style) } \\
\end{array}$ & $\begin{array}{c}\text { Demographic survey } \\
\text { Prior knowledge checklist } \\
\text { Retention test } \\
\text { Transfer test } \\
\text { Cognitive load items } \\
\text { Intrinsic motivation items }\end{array}$ & $\begin{array}{l}\text { ANOVA \& } \\
\text { ANCOVA }\end{array}$ & $\begin{array}{l}\text { Learning with an animated } \\
\text { pedagogical agent was } \\
\text { more interesting } \\
\text { Conversational style } \\
\text { enhanced retention. } \\
\text { Students attracted to the } \\
\text { agents } \\
\end{array}$ & $\begin{array}{c}\text { Future research may need to } \\
\text { investigate further the potential } \\
\text { effects of gender ethnicity and with } \\
\text { a large sample size }\end{array}$ \\
\hline 2 & $\begin{array}{l}\text { Sinclair et al. } \\
\text { (2019) }\end{array}$ & Experimental & $\begin{array}{l}\text { Corpora and Corpus } \\
\text { (lexicon-grammar, } \\
\text { vocabularies specific)- } \\
\text { Expression Lexicon, } \\
\text { Expression Variety, } \\
\text { Expression Repetition, } \\
\text { Vocabulary Overlap }\end{array}$ & $\begin{array}{l}\text { Toolkit scikit- } \\
\text { learn2 } \\
\text { Bayesian } \\
\text { Gaussian } \\
\text { mixture }\end{array}$ & $\begin{array}{l}\text { Significant alignment in } \\
\text { learning }\end{array}$ & $\begin{array}{l}\text { It would like to collect data in a } \\
\text { controlled setting that is more } \\
\text { similar to the Tutorbot Corpus to } \\
\text { facilitate in-depth comparison } \\
\text { Another avenue for future research } \\
\text { is the design of adaptive } \\
\text { 'alignment' moves for the } \\
\text { automated tutor }\end{array}$ \\
\hline 3 & $\begin{array}{l}\text { McDonough et } \\
\text { al. (2019) }\end{array}$ & $\begin{array}{c}\text { Experimental } \\
\text { (Pre-test and Post-tests) }\end{array}$ & $\begin{array}{c}\text { Grammar test } \\
\text { Interactive activities } \\
\text { Oral tests }\end{array}$ & $\begin{array}{l}\text { M, std, \& t-test } \\
\text { Relative clause } \\
\quad \text { coding }\end{array}$ & $\begin{array}{l}\text { Received explicit } \\
\text { information through } \\
\text { interactive practices }\end{array}$ & $\begin{array}{l}\text { Future research would like to } \\
\text { explore the effectiveness of } \\
\text { implementing interactive practice } \\
\text { activities in authentic CLT } \\
\text { classrooms and incorporating } \\
\text { interactive practices into } \\
\text { instructional routines }\end{array}$ \\
\hline 4 & Asmali (2018) & $\begin{array}{c}\text { Experimental } \\
\text { (Pre-test and Post-tests) CG } \\
\& \mathrm{EG}\end{array}$ & Questionnaire & $\begin{array}{l}\text { Mann-Whitney U } \\
\text { test, } \\
\text { Wilcoxon Signed } \\
\text { Rank test } \\
\end{array}$ & $\begin{array}{l}\text { Better performance, higher } \\
\text { tendency of simulation, } \\
\text { positive attitudes towards } \\
\text { the use of clickers }\end{array}$ & $\begin{array}{l}\text { Longitudinal effects of the use of } \\
\text { clickers and students' as well as } \\
\text { instructors' views may also be } \\
\text { investigated in the future study }\end{array}$ \\
\hline 5 & $\begin{array}{l}\text { Sert et al. } \\
\quad(2017)\end{array}$ & $\begin{array}{l}\text { Non-Experimental: } \\
\text { Correlation Research }\end{array}$ & $\begin{array}{c}\text { Survey } \\
\text { (Open ended questions) }\end{array}$ & $\begin{array}{l}\text { M, std, \& t-test } \\
\text { Pearson } \\
\text { correlation } \\
\text { Spearman's rho } \\
\end{array}$ & $\begin{array}{c}\text { Social stratum of the } \\
\text { students has made no } \\
\text { difference for using digital } \\
\text { technology }\end{array}$ & $\begin{array}{c}\text { More comprehensive qualitative, } \\
\text { quantitative, and/ or mixed studies } \\
\text { can conduct }\end{array}$ \\
\hline 6 & $\begin{array}{l}\text { Mohammadza } \\
\text { deh et al. } \\
\text { (2018) }\end{array}$ & $\begin{array}{c}\text { Mixed method: } \\
\text { Quasi-experimental } \\
\text { (Pre-test, post-test design) } \\
\text { Qualitative (questionnaire) }\end{array}$ & $\begin{array}{l}\text { Oxford placement test, } \\
\text { IELTS speaking Test (pre- } \\
\text { test, immediate post-test, } \\
\text { delayed post-test) } \\
\text { Questionnaire-Likert scale } \\
\text { Autotutor software } \\
\text { conversation model }\end{array}$ & $\begin{array}{l}\text { Kruskal-Wallis } \\
\text { test, } \\
\text { A repeated } \\
\text { measures ANOVA } \\
\text { Descriptive } \\
\text { statistics } \\
\end{array}$ & $\begin{array}{l}\text { Significant improvements of } \\
\text { implementation of SRL } \\
\text { through intelligent tutoring } \\
\text { system, assist them in } \\
\text { learning effectively, } \\
\text { supporting them, corrective } \\
\text { feedback, prompts and } \\
\text { hints for completing tasks }\end{array}$ & $\begin{array}{l}\text { Large sample can do how } \\
\text { technology can effectively enhance } \\
\text { SRL to assist learners in improving } \\
\text { their speaking ability }\end{array}$ \\
\hline 7 & Pan (2017) & $\begin{array}{c}\text { Experimental: } \\
3 \text { group design-control } \\
\text { Traditional computer- } \\
\text { mouse interface X2 } \\
\text { Motion-sensing X1 } \\
\text { (Pre-test, treatment, Post- } \\
\text { test, delayed post-test) } \\
\end{array}$ & $\begin{array}{l}\text { English vocabulary } \\
\text { cognition test }\end{array}$ & $\begin{array}{l}\text { F-test, } \\
\text { two-way mixed- } \\
\text { designed ANOVA, } \\
\text { Descriptive } \\
\text { statistic }\end{array}$ & $\begin{array}{l}\text { Significant long-term } \\
\text { retention }\end{array}$ & $\begin{array}{l}\text { A true-experimental design should } \\
\text { adopt to control the interference } \\
\text { factors better in future studies, and } \\
\text { teachers can also use the novel } \\
\text { KMIS interface }\end{array}$ \\
\hline 8 & $\begin{array}{l}\text { Carlotto et al. } \\
\qquad(2016)\end{array}$ & $\begin{array}{c}\text { Experimental } \\
\text { (Pre-test, post-test design) }\end{array}$ & Murphy’s English grammar & $\begin{array}{l}\text { Descriptive } \\
\text { statistics } \\
\text { ANOVA }\end{array}$ & $\begin{array}{l}\text { The voice of the agent } \\
\text { contribute more positively } \\
\text { to learning }\end{array}$ & $\begin{array}{l}\text { It can explore which instructional } \\
\text { conditions affect the appearance } \\
\text { of the image effect is an issue for } \\
\text { future work }\end{array}$ \\
\hline 9 & & Li et al. (2015) & $\begin{array}{c}\text { Experimental } \\
\text { (Pre-test, treatment, Post- } \\
\text { test) }\end{array}$ & $\begin{array}{l}\text { Gates MacGinitie } \\
\text { reading test }\end{array}$ & $\begin{array}{l}\text { One-way ANCOVA } \\
\text { Regression } \\
\text { ANCOVA } \\
\end{array}$ & $\begin{array}{c}\text { Higher performance, improved } \\
\text { learning outcomes, enhanced } \\
\text { student engagement }\end{array}$ \\
\hline
\end{tabular}

